\title{
Adaptation of Individual and Team Character in Sport Questionnaire to Turkish
}

\author{
İlyas Görgüt ${ }^{1}$, Erkut Tutkun ${ }^{2}$ \\ ${ }^{1}$ Dumlupınar University, School of Physical Education and Sport, Kütahya, Turkey \\ ${ }^{2}$ Uludag University, Faculty of Sport Sciences, Bursa, Turkey \\ Correspondence: Erkut Tutkun, Uludag University, Faculty of Sport Sciences, Bursa, Turkey.
}

Received: August 13, 2017

doi:10.11114/jets.v5i10.2593
Accepted: September 14, $2017 \quad$ Online Published: September 18, 2017

URL: https://doi.org/10.11114/jets.v5i10.2593

\begin{abstract}
The aim of this study was to make validity and reliability of Turkish form of the individual and team character in sport questionnaire (ITCSQ) which was developed by Davidson et al., (2000). Scale was designed to measure outcomes related with character in the sport environment. 438 participants were voluntarily included into the study in two stages as pilot and main study. After the controlling of the answers, incorrect and incompletely filled scale forms were taken out, 170 people were taken for the pilot study and 268 people were taken into the consideration for the validity and reliability of the scale. Firstly, language validity was provided through expert opinion. Validity of scale to Turkish culture was assessed with confirmatory factor analysis and reliability of scale was assessed with split-half reliability methods and it was seen that fit indices were in acceptable level for six subscales. In conclusion, the internal consistency for all scale was .83 and for the six subscale respectively were $.74, .80, .82$. Obtained data by the application of Turkish form of scale showed that adapted scale which had 3 factors, 44 items and 5 Likert type scoring tool, was a valid and reliable scale.
\end{abstract}

Keywords: sport, individual, team, character, scale, validity, reliability

\section{Introduction}

By nature, human beings are moving entities and the importance of movement has been emphasized in the development of human beings since the ancient times (Proios et al., 2010). The assumptions which require physical activity such as sports or physical education develop morals or character are especially stressed and they attract the attention of researchers.

Character is an individual's unique nature, being at peace with oneself and having self-control (TDK, 2017). Although this concept has been expressed differently within time, its general meaning comes from the Greek root of "charassein" and is defined as integrity and unconditional acceptance (Jakubowski, 2013). Character is the visible manifestation of a few processes related with each other. It is showing honesty, respect, determination or courage and the end product of one or more psychological processes and mostly it is expressed as three general categories related to each other and almost impossible to seperate from each other as cognition, impact and behavior (Davidson et al., 2004). Since sport is a multidisciplinary area that influences and develops all these categories as a whole, and since it is seen as a tool by some researchers in learning and debating through cooperation with team mates, creating solutions to moral disputes and teaching self-control, fairness and ethics (Weiss and Bredemeier, 1990; Shields and Bredemeier, 1995, cited from Gaines, 2012), it is an important tool in shaping individuals' character. The assumption that participation in sports can influence character development and character development can influence participation in physical activity and sports shows that bilateral association between character and participation in sport (Laborde, Guillen and Mosley, 2016). Thus, it is thought that a great number of options such as the type of sport branch, whether it is a team sport and whether it is done individually or as a group can influence the individuals in different levels.

All sports can provide a chance for moral reasoning. However, team sports and group activities have the potential to develop values such as integrity, responsibility and cooperation (Wandzilak, 1985). For this reason, team character is the collective structure of all the values that prepare each member of the team to act in terms of morals and it is a model of intentions (Petrick and Quinn, 1997). Norms shared by teams create significant effects on individual team members' moral reasoning and behaviors. The number of friends who would show aggressive behaviors under similar conditions considered as moral atmosphere and motivating variables is seen as the greatest predictor of athletes' aggression attempts. 
That is, athletes' perceptions about team norms are the most consistent prediction tools for cheating or aggression behaviors that express them. In addition, there are also studies in literature which show that athletes' perceptions of cheating or aggression behaviors that coaches ask from athletes for team norms or team atmosphere are more effective than the cheating or aggression states that their best friends, most popular players, team captains or parents will ask from them. Thus, the coach's role is not to impose ideas or roles, but to encourage, ease and lead the necessary dialogue that causes an understanding, common interest and mutual commitments (Nucci et al., 2008). The team should be turned into a value based community because moral wish should be formed both irreducibly individually and also socially. Team is assessed in social dimension since it reflects a deep moral wish such as fairness, mercy, affection, respect and responsibility and because of the necessity of living moral commitment in a society, and also in individual dimension because of athletes' tendency of training themselves more in order to gain experience. Careful coaches can make use of the advantages of situations by turning their teams into affectionate and responsible communities which accept moral values as the core of communities. In addition, coaches can encourage team dialogue to create a moral environment suitable for character development and positive social behavior; they can focus on common benefits and encourage common responsibility (Power et al., 1989). Thus, individual and team character analysis will be useful in terms of an athlete's adapting to the environment he is in, that is identifying with the team, in addition in terms of coach's seeing the general tendencies of the group while designing the sport environment. For this reason, individual and team character in sport scale was adapted to Turkish culture and was accessed to the use of researchers. This scale gives researchers the opportunity to assess athletes' points of view about to what extent team mates are in harmony with them, that is how much they reflect them in terms of individual dimension; to assess team mates' views about interest-commitment and collective responsibility, that is, their states of assessing friends and interpreting their behaviors and lastly, to assess athletes' point of view about coaches' attitudes towards transferring values or experiences of developing character.

\section{Method}

Turkish adaptation of individual and team character in sport questionnaire was realized by following the scientific steps that should be followed in adaptation studies such as language validity, pilot application of scale items and validity and reliability studies.

Study group: The research includes two parts. In the first part of the research, participants were reached for pilot study. At this stage, 170 individuals were included in the pilot study and the answers of 12 individuals who did not respond suitably for the questionnaire form were not assessed. In the second part, 268 individuals were included in the validity and reliability studies of the data collection tool and again in this part, the answers of 16 individuals were taken out. Studies in literature show that the number of participants reached is sufficient for adaptation studies. Related with this issue, while Tabachnick and Fidell (2007) state that at least 300 people should take part in factor analysis studies, Bryman and Cramer (2001) stated this number to be five or ten times the number of items in the scale, and Hair et al. (1998) stated that a group as big as the five times of the total number of items in the scale was sufficient for adaptation studies of a group.

Original form used for adaptation studies: "The individual and team character in sport questionnaire" which was adapted into Turkish, was developed by Davidson et al., (2000). The original form consists of 3 dimensions and 48 items. The first scale is the "value rating" scale. In this dimension, there are expressions which aim to measure values such as sportsmanship, personal responsibility and perseverance. The second scale is "community climate" scale and it is divided in two sub-dimensions as caring and connectedness and collective responsibility, and it includes participants' caring and acceptance to their friends. The third scale is "character development experiences" scale and it includes expressions about the coaches' experiences about character supporting experiences. Alpha values for sub-dimensions were found as .80 for Values Rating, .73 for Caring and Connectedness, .83 for Collective Responsibility and .81 for Character Development Experiences and 4 Likert type rating was used in the scale.

Data analysis and procedure: The adaptation study was started with regard to the expression of the authors who developed the scale that "it may be used or duplicated without permission of the authors". First, through translate-retranslate method, the scale was translated into Turkish by experts in their field, later, it was retranslated into English, with the help of other experts the scale was checked for semantic shift, when it was seen that there was no shift, it was decided to use the form translated into Turkish.

Meydan and Şeşen (2011) state that Confirmatory Factor Analysis (CFA) is a method which is used to test whether the data in hand fits the original structure discovered previously (cited from: Seçer, 2015). Thus, CFA was used to test whether the scale was suitable for Turkish culture. Through lisrel analysis program, the data obtained were checked for fit values of CFA such as X2/df, RMSEA, CFI, NNFI, NFI, IFI, RFI, GFI and AGFI. 


\section{Results}

Table 1. Participants' age/gender distributions

\begin{tabular}{lllllll}
\hline \multirow{2}{*}{ Age } & \multicolumn{2}{l}{ Gender } & \multicolumn{3}{c}{ Women } & Total \\
& Men & \multicolumn{3}{l}{$n$} & \multicolumn{1}{c}{$n$} & $\%$ \\
\cline { 2 - 5 } 18 and younger & 12 & 2.7 & 9 & 2.1 & 21 & 4.8 \\
19-20 years of age & 80 & 18.3 & 104 & 23.7 & 184 & 42.0 \\
21-22 years of age & 84 & 19.2 & 53 & 12.1 & 137 & 31.3 \\
23-24 years of age & 46 & 10.5 & 16 & 3.7 & 62 & 14.2 \\
25 and older & 32 & 7.3 & 2 & 0.5 & 34 & 7.8 \\
Total & 254 & 58.0 & 184 & 42.0 & 438 & 100.0 \\
\hline
\end{tabular}

According to Table 1, when the participants' age distributions were examined, it was found that $4.8 \%$ were in the age group of 18 and younger, $42 \%$ were in the age group of $19-20,31.3 \%$ were in the age group of $21-22,14.2 \%$ in the age group of 23-24 and 7.8\% were in the age group of 25 and older.

Table 2. Participants' branch/gender distributions

\begin{tabular}{lllllll}
\hline \multirow{2}{*}{ Branch } & \multicolumn{2}{l}{ Gender } & Women & \\
& Men & \multicolumn{3}{l}{ Total } \\
& $n$ & $\%$ & $n$ & $\%$ & $n$ & $\%$ \\
\hline Football & 130 & 29.7 & 50 & 11.4 & 180 & 41.1 \\
Volleyball & 19 & 4.3 & 39 & 8.9 & 58 & 13.2 \\
Basketball & 24 & 5.5 & 17 & 3.9 & 41 & 9.4 \\
Handball & 11 & 2.5 & 18 & 4.1 & 29 & 6.6 \\
Athleticism & 9 & 2.1 & 14 & 3.2 & 23 & 5.3 \\
Judo & 8 & 1.8 & 12 & 2.7 & 20 & 4.6 \\
Gymnastics & 2 & 0.5 & 16 & 3.7 & 18 & 4.1 \\
Wrestling & 22 & 5.0 & 0 & 0.0 & 22 & 5.0 \\
Kickboxing & 12 & 2.7 & 4 & 0.9 & 16 & 3.7 \\
Boxing & 2 & 0.5 & 7 & 1.6 & 9 & 2.1 \\
Karate & 3 & 0.7 & 2 & 0.5 & 5 & 1.1 \\
Badminton & 0 & 0.0 & 3 & 0.7 & 3 & 0.7 \\
Muay Thai & 2 & 0.5 & 1 & 0.2 & 3 & 0.7 \\
Taekwondo & 3 & 0.7 & 0 & 0.0 & 3 & 0.7 \\
Rowing & 2 & 0.5 & 0 & 0.0 & 2 & 0.5 \\
Table tennis & 2 & 0.5 & 0 & 0.0 & 2 & 0.5 \\
Dart & 2 & 0.2 & 0 & 0.0 & 2 & 0.5 \\
Shooting & 0 & 0.0 & 1 & 0.2 & 1 & 0.2 \\
Bocce & 1 & 0.2 & 0 & 0.0 & 1 & 0.2 \\
Total & 254 & 58.0 & 184 & 42.0 & 438 & 100.0 \\
\hline
\end{tabular}

Table 2 gives the distribution of the participants in terms of their branches. It can be seen that the branches of $41.1 \%$ were football, $13.2 \%$ were volleyball, $9.4 \%$ were basketball and $6.6 \%$ were handball.

Table 3. Participants' Experience in Sports /Gender Distribution

\begin{tabular}{lllllll}
\hline \multirow{2}{*}{ Experience in Sports } & \multicolumn{2}{l}{ Gender } & \multicolumn{3}{c}{ Total } \\
& Men & \multicolumn{3}{l}{ Women } & \\
& $n$ & $\%$ & $n$ & $\%$ & $n$ & $\%$ \\
\hline 5 Years and less & 38 & 8.7 & 72 & 16.4 & 110 & 25.1 \\
6-8 Years & 52 & 11.9 & 53 & 12.1 & 105 & 24.0 \\
9-11 Years & 91 & 20.8 & 45 & 10.3 & 136 & 31.1 \\
12-14 Years & 46 & 10.5 & 11 & 2.5 & 57 & 13.0 \\
15 Years and more & 27 & 6.2 & 3 & 0.7 & 30 & 6.8 \\
Total & 254 & 58.0 & 184 & 42.0 & 438 & 100.0 \\
\hline
\end{tabular}

When the distribution of the participants were examined in terms of their experience in sports, it was found that $25.1 \%$ had 5 years and less experience in sports, $24 \%$ had 6-8 years of experience in sports, $31.1 \%$ had $9-11$ years of experience in sports, $13.1 \%$ had $12-14$ years of experience in sports and $6.8 \%$ had 15 years and more experience in sports. 
Table 4. Distribution of ITCSQ items in terms of dimensions and sub-dimensions

\begin{tabular}{ll}
\hline Dimension & Item Number \\
\hline $\begin{array}{l}\text { Values rating } \\
\begin{array}{l}\text { Community Climate } \\
\text { (Caring/Connectedness, }\end{array}\end{array}$ & $1,2,3,4,5,6,7,8,9,10,11,12,13,14,15,16$ \\
$\begin{array}{l}\text { Responsibility) } \\
\text { Character Development Experiences }\end{array}$ & $33,34,35,36,37,38,39,40,41,42,43,44,45,46,47,48$ \\
\hline
\end{tabular}

Table 4 gives the distribution of scale items in terms of dimensions. It can be seen that the dimensions of "Values rating", "Community Climate (Caring/Connectedness, Collective Responsibility)" and "Character Development Experiences" each have 16 items.

Table 5. Results of Pilot Study

\begin{tabular}{|c|c|c|c|}
\hline & Corrected Total Item Correlation & & Corrected Total Item Correlation \\
\hline Item1 & .30 & Item 25 & .48 \\
\hline Item $2 *$ & .44 & Item $26^{*}$ & .54 \\
\hline Item 3 & .41 & Item 27 & .47 \\
\hline Item $4 *$ & .18 & Item 28 & .43 \\
\hline Item $5^{*}$ & .35 & Item $29 *$ & .35 \\
\hline Item 6 & .34 & Item 30 & .61 \\
\hline Item 7 & .42 & Item 31 & .49 \\
\hline Item 8 & .37 & Item $32 *$ & .40 \\
\hline Item $9 *$ & .39 & Item 33 & .51 \\
\hline Item 10 & .41 & Item 34 & .59 \\
\hline Item 11 & .37 & Item 35 & -.14 \\
\hline Item $12 *$ & .31 & Item 36 & .44 \\
\hline Item 13 & .18 & Item 37 & .23 \\
\hline Item $14 *$ & .35 & Item 38 & .39 \\
\hline Item 15 & .33 & Item 39 & .47 \\
\hline Item 16 & .38 & Item 40 & .57 \\
\hline Item 17 & .52 & Item 41 & .54 \\
\hline Item 18 & .42 & Item 42 & .36 \\
\hline Item $19^{*}$ & .30 & Item 43 & .42 \\
\hline Item 20 & .41 & Item 44 & .41 \\
\hline Item 21 & .42 & Item 45 & .63 \\
\hline Item 22 & .55 & Item $46^{*}$ & .30 \\
\hline Item $23^{*}$ & .55 & Item 47 & .56 \\
\hline Item 24 & .32 & Item 48 & .44 \\
\hline
\end{tabular}

\section{*reversed items}

Table 5 shows that as a result of pilot study, the corrected total item correlation distributions of items differed between -.20 (item35) and .63 (item45), while internal consistency coefficient was found to be .91 . However, when the items which have less than .30 item total correlation are deleted, internal consistency coefficient becomes .93. Thus, items 4,13 , 35 and 37 which had less than .30 item total correlation were deleted.

Table 6. CFA results of the items of the scale

\begin{tabular}{llllll}
\hline Fit index & $\begin{array}{l}\text { Perfect fit } \\
\text { criterion }\end{array}$ & $\begin{array}{l}\text { Acceptable } \\
\text { criterion }\end{array}$ & fit & $\begin{array}{l}\text { Research } \\
\text { finding }\end{array}$ & Result \\
\hline X2/df & $\leq 3$ & $4-5$ & 2.09 & Perfect fit \\
RMSEA & $\leq .05$ & $.05-.10$ & $0.064 * *$ & Acceptable fit \\
CFI & $\geq .95$ & $\geq .90$ & 0.90 & Acceptable fit \\
NNFI & $\geq .95$ & $\geq .90$ & 0.91 & Acceptable fit \\
NFI & $\geq .95$ & $\geq .90$ & 0.92 & Acceptable fit \\
IFI & $\geq .95$ & $\geq .90$ & 0.92 & Acceptable fit \\
RFI & $\geq .95$ & $\geq .90$ & 0.90 & Acceptable fit \\
GFI & $\geq .90$ & $\geq .85$ & 0.85 & Acceptable fit \\
AGFI & $\geq .90$ & $\geq .85$ & 0.86 & Acceptable fit \\
\hline
\end{tabular}

*Reference: (Seçer, 2015, p. 122; Meydan and Şeşen, 2011, p.37; ${ }^{* *}$ MacCallum et al., 1996, cited from: Hooper et al, 2008, p. 54).

First level confirmatory factor analysis and later on modification changes were conducted on the scale form which consisted of 44 items; however, it was found that there were items with item factor loads of less than .30 and that these 
items decreased fit values (item1, item 2, item 5, item 10, item 19, item 23, item 27, item 46). Thus, after these items were deleted, confirmatory factor analysis was reconducted with the remaining 36 items. In the light of the data obtained, it was found that X2/df value had "perfect fit", while RMSEA, CFI, NNFI, NFI, IFI, RFI, GFI and AGFI values had "acceptable fit". The finalized Path diagram is given below.

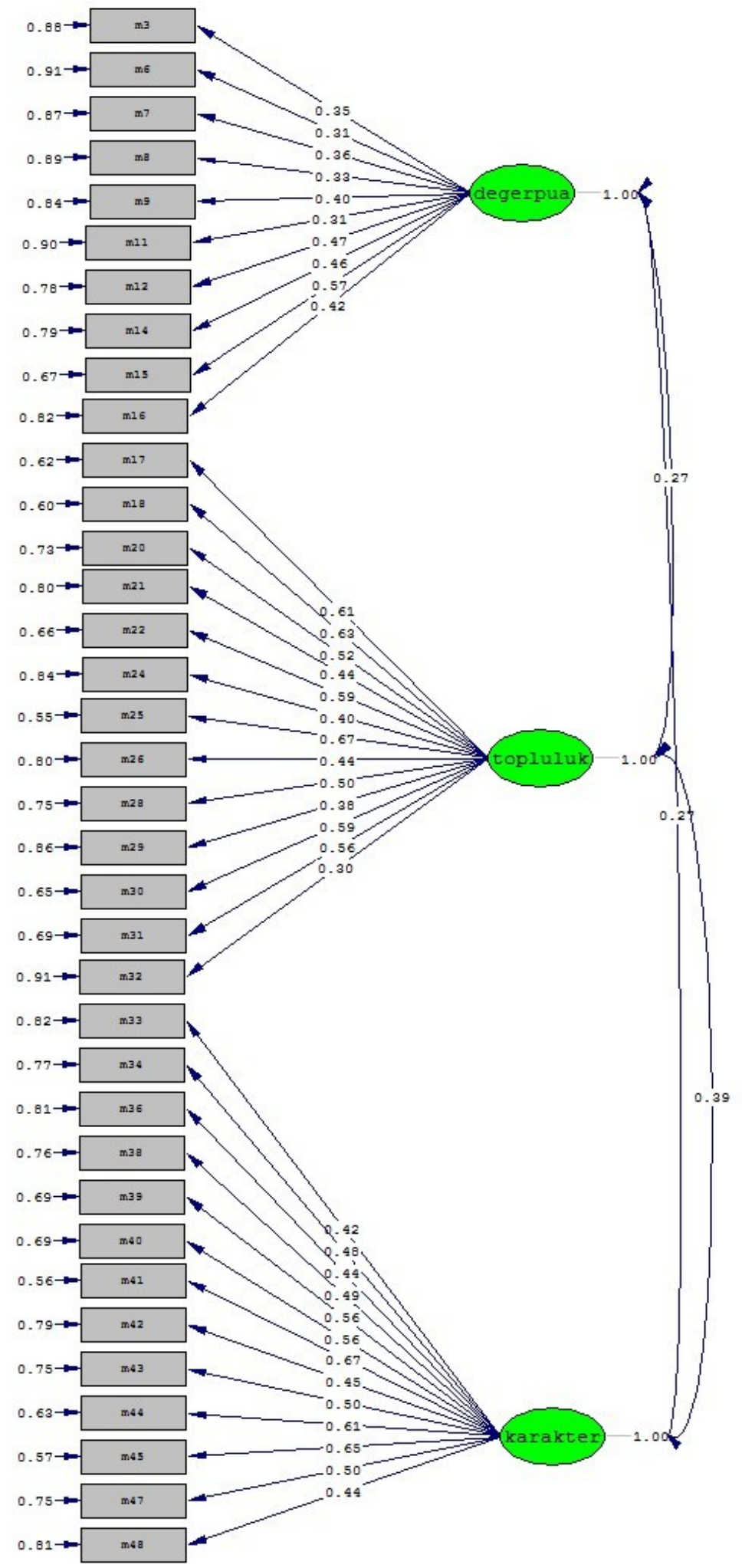

Chi-3quare $=1240.01, \mathrm{df}=591, \mathrm{P}-\mathrm{value}=0.00000, \mathrm{RMSEA}=0.064$

Figure 1. Path diagram of first-level confirmatory factor analysis 
When the Path diagram is examined, it can be seen that item factor loads differ between 0.30 and .67.

Table 7. Reliability results of the scale

\begin{tabular}{lcc}
\hline Dimensions & Internal consistency & Split half reliability \\
\hline Values rating & .74 & .75 \\
Community Climate & .80 & .73 \\
Character Development Experiences & .82 & .73 \\
Total Scale & .83 & .87 \\
\hline
\end{tabular}

Table 7 gives the reliability results of the scale. Total internal consistency of the scale was .83 , while split half test reliability was .87 . Internal consistency and split half reliability results of the sub-dimensions were $.74 / .75$ for values rating sub-dimension, $.80 / .73$ for community climate sub-dimension and $.82 / .73$ for character development experiences sub-dimension.

\section{Discussion and Conclusion}

In sports environment, scales are commonly resorted methods to determine the existing states and expectations of participants about characters and values. Jang (2013) developed a sport character scale and in this scale, there were 27 expressions that athletes were asked to answer in the sub-dimensions of honesty, anti-sociality, compassion, sportsmanship and fairness. For the sub-dimensions, alpha values were found as .91 for honesty, .87 for anti-sociality, .79 for compassion, .83 for sportsmanship and .91 for fairness and 6-likert type was used for scale rating. Doty (2005) also developed a scale to determine the sports characteristics of participants to sports activities in United Nations military academy. Carron et al., (1999) developed a team norm scale to predict the power of collective team expectations within the framework of team norms defined by Munroe et al. (1999) related with the athletes' competition, training, out-of-season and social states. Similarly, Shields et al. (1995) developed a team norms scale that banned cheating and aggression. In their study they conducted on adolescent athletes who did team sports, Guiverneau and Duda (2002) developed a scale by making changes in moral atmosphere measurements to examine the effects of aggression potential in a wider range (Nucci et al., 2008). Widmeyer, Brawley and Carron (1985) developed a group environment scale. A scale is a tool that measures team unity both socially and also as a duty and it is a tool that is resorted in studies about team unity. In addition, Stephens et al. conducted a study of "moral behavior judgments in young athletes" to determine the moral behavior judgments of athletes who do team sports (Bredemeier, 1994; Stephens et al., 1997). Gürpınar (2014) conducted a study to adapt "attitudes of taking moral decisions in infrastructure sports" scale into Turkish.

As a conclusion, there are scales of determining norms within a team or internalizing with the team, interests with the team and the team character. However, since such studies are limited in our country and such scales are needed, the adaptation of "Individual and Team Character in Sport Questionnaire" was checked for adaptation to Turkish culture and the questionnaire form was adapted and presented for the use of researchers by following the necessary scientific steps. In Turkish adaptation, Individual and Team Character in Sport Questionnaire (appendix 1) has three factors and 36 items in total. In the Turkish questionnaire form, items 5, 7, 8, 18, 20 and 23 are scored reversely. In addition, the fact that total item correlation values obtained as a result of findings differ between .30 and .67 shows that the values calculated for the questionnaire are sufficient. As a conclusion, since the adapted scale has an internal consistency coefficient greater than .70 and item total correlation greater than .30 (Büyüköztürk, 2007) and meets sufficient CFA fit indices (Seçer, 2015; Meydan and Şeşen, 2011; MacCallum et al., 1996, cited from: Hooper et al, 2008, p. 54), it can be said that "Individual and Team Character in Sport Questionnaire" is a suitable, valid and reliable scale for Turkish culture.

\section{References}

Bredemeier, B. J. L. (1994). Children's moral reasoning and their assertive, aggressive, and submissive tendencies in sport and daily life. Journal of Sport \& Exercise Psychology, 64, 1-14. https://doi.org/10.1123/jsep.16.1.1

Bryman, A., \& Cramer, D. (2001). Quantitative Data Analysis with SPSS Release 1o for Windows, Routledge, London.

Büyüköztürk, Ş. (2007). Sosyal Bilimler İçin Veri Analizi El Kitabı (21. Baskı). Ankara: Pegem akademi yayınları.

Carron, A. V., Prapavessis, H., \& Estabrooks, P. (1999). Team Norm Questionnaire. Unpublished. School of Kinesiology, University of Western Ontario, London, on, Canada.

Davidson, M. L., Khmelkov, V. T., \& Moran-Miller, K. E. (2000). Individual and Team Character in Sport Questionnaire (ITCSQ). SUNY Cortland, PO Box.

Davidson, M. L., Moran-Miller, K., \& Beedy. J. P. (2004) Performance and Moral Character: A Blueprint for Developing Character in Competitive Contexts. Center for the 4th and 5th Rs., 1-23.

Doty, J. P. (2005). The development and validation of an instrument to measure character in sport at the U.S. Military Academy. Unpublished doctoral dissertation, University of Northern Colorado, CO. 
Gaines, S. A. (2012) Theory into practice: developing individual and team character in sport, Strategies, 25(8), 30-33, https://doi.org/10.1080/08924562.2012.10592180

Gürpınar, B. (2014). Altyapı Sporlarında Ahlaki Karar Alma Tutumları Ölçeğinin Türk Kültürüne Uyarlanması: Bir Türk Örnekleminde Geçerlik ve Güvenirlik Çalışması. Eğitim ve Bilim, 39(176).

Hair, J. F., Anderson, R. E., Tatham, R. L., \& Black, W. C. (1998). Multivariate data analysis (5th ed.). Upper Saddle River, NJ: Prentice-Hall.

Hooper, D., Coughlan, J., \& Mullen, M. (2008). Structural equation modelling: Guidelines for determining model fit. Articles, 2.

Jang, C. Y. (2013). Development and validation of the sport character scale. Doctorate thesis, The University of Utah, USA.

Meydan, C. H., \& Şeşen, H. (2011). Yapısal Eşitlik Modellemesi AMOS Uygulamaları (1.Baskl). Ankara: Detay Yayıncilik.

Nucci, L. P., Krettenauer, T., \& Narváez, D. (Eds.). (2008). Handbook of moral and character education. Routledge.

Petrick, J. A., \& Quinn, J. F. (1997). Management ethics: Integrity at work (Vol. 6). Sage.

Power, C., Higgins, A., \& Kohlberg, L. A. (1989). Lawrence Kohlberg's approach to moral education. New York: Columbia University Press.

Proios, M., Athanailidis, I., \& Giannitsopoulou, E. (2010). The impact of physical activities on the development of the females' character. Special Artical, Journal of Human Sport \& Exercise. https://doi.org/10.4100/jhse.2010.53.18

Seçer, İ. (2015). Psikolojik test geliştirme ve uyarlama süreci (1.Baskl). Ankara: Anı yayınc1lı. ISSBN: 978-605-170-014-4

Stephens, D. E., Bredemeier, J. L., \& Shields, D. L. L. (1997). Construction of a measure designed to assess players' descriptions and prescriptions for moral behavior in youth sport soccer. International Journal of Sport Psychology, 28(4), 370-390.

Tabachnick, B. G., \& Fidell, L. S. (2007). Using multivariate statistics (5th ed.). Boston, MA: Allyn \& Bacon. TDK. (2017). Karakter. Güncel Türkçe Sözlük. $\quad$ retrieved 20.02 .2017 http://www.tdk.gov.tr/index.php?option=com_gts\&kelime=KARAKTER.

Wandzilak, T. (1985). Values development through physical education and athletics, Quest, 37:2, 176-185. https://doi.org/10.1080/00336297.1985.10483832

Widmeyer, W. N., Brawley, L. R., \& Carron, A. V. (1985). The Measurement of Cohesion in Sport Teams: The Group Environment Questionnaire. London, Ontario. Sports Dynamics. 


\section{Appendix: Questionnaire Form}

\begin{tabular}{|c|c|c|c|c|c|c|}
\hline \multicolumn{2}{|r|}{$\begin{array}{l}\text { 1. Below are descriptions of the way different people think or act. Please mark the answer that } \\
\text { describes how much these people are LIKE YOU. These people, }\end{array}$} & 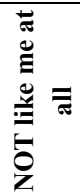 & 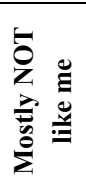 & 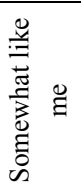 & 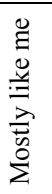 & 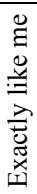 \\
\hline 1 & Show respect to their teammates, even if they do not agree with them. & 1 & 2 & 3 & 4 & 5 \\
\hline 2 & Do not give up and they keep trying after they have made a mistake. & 1 & 2 & 3 & 4 & 5 \\
\hline 3 & Are never rude to players on the other team. & 1 & 2 & 3 & 4 & 5 \\
\hline 4 & Take time outside of practice to improve their skills. & 1 & 2 & 3 & 4 & 5 \\
\hline 5 & Make negative comments about their coaches to each other.* & 1 & 2 & 3 & 4 & 5 \\
\hline 6 & Congratulate opponents who have played well or won. & 1 & 2 & 3 & 4 & 5 \\
\hline 7 & Believe it is OK not to obey the rules as long as they don't get caught.* & 1 & 2 & 3 & 4 & 5 \\
\hline 8 & Would hurt an opponent if it would help them to win the game. ${ }^{*}$ & 1 & 2 & 3 & 4 & 5 \\
\hline 9 & Continue to play hard, even if their team is losing. & 1 & 2 & 3 & 4 & 5 \\
\hline 10 & Can be counted on to do their part of the team. & 1 & 2 & 3 & 4 & 5 \\
\hline
\end{tabular}

\begin{tabular}{|c|c|c|c|c|c|c|}
\hline & 2. Think about your teammates. Do you agree or disagree with these statements about them? & 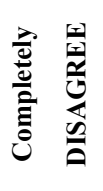 & 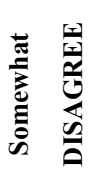 & $\begin{array}{l}0 \\
\vdots \\
\tilde{n} \\
\stackrel{0}{Z} \\
z\end{array}$ & 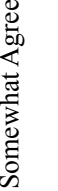 & 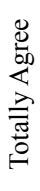 \\
\hline 11 & Players trust each other. & 1 & 2 & 3 & 4 & 5 \\
\hline 12 & $\begin{array}{l}\text { When players hurt another teammate, they try to make up for it (by apologizing, or doing } \\
\text { something nice). }\end{array}$ & 1 & 2 & 3 & 4 & 5 \\
\hline 13 & Players care about each other. & 1 & 2 & 3 & 4 & 5 \\
\hline 14 & Players on this team are kind to one another. & 1 & 2 & 3 & 4 & 5 \\
\hline 15 & Players on this team encourage one another, even when they are losing. & 1 & 2 & 3 & 4 & 5 \\
\hline 16 & When the players on this team see someone being picked on, they try to stop this. & 1 & 2 & 3 & 4 & 5 \\
\hline 17 & Players encourage one another, even those who aren't very good athletes. & 1 & 2 & 3 & 4 & 5 \\
\hline 18 & Players who aren't very good athletes are picked on or are excluded. * & 1 & 2 & 3 & 4 & 5 \\
\hline 19 & Players work together to develop new skills. & 1 & 2 & 3 & 4 & 5 \\
\hline 20 & Players don't care if their team mates cheat to win.* & 1 & 2 & 3 & 4 & 5 \\
\hline 21 & Players try to get their teammates to follow the team rules. & 1 & 2 & 3 & 4 & 5 \\
\hline 22 & Players take extra time to help their team mates who are struggling. & 1 & 2 & 3 & 4 & 5 \\
\hline 23 & Players gossip about one another.* & 1 & 2 & 3 & 4 & 5 \\
\hline
\end{tabular}




\begin{tabular}{|c|c|c|c|c|c|c|c|}
\hline \multicolumn{2}{|r|}{ 3. Think about the coaches and your team. How FREQUENTLY did the following happen? } & \multirow{2}{*}{ 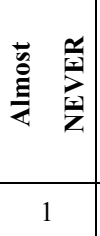 } & \multirow{2}{*}{$\begin{array}{l}\frac{\lambda}{0} \\
\stackrel{\vec{\Xi}}{\approx} \\
2\end{array}$} & \multirow{2}{*}{ 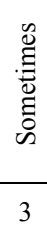 } & \multirow{2}{*}{ 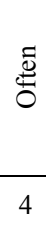 } & \multirow{2}{*}{\multicolumn{2}{|c|}{ 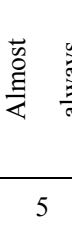 }} \\
\hline 24 & The coaches talked to me about moral values (such as respect, responsibility, fairness ). & & & & & & \\
\hline 25 & The coaches were available to talk with players about problems that were bothering them. & 1 & 2 & 3 & 4 & 5 & \\
\hline 26 & The coaches talked to me about the importance of my role on the team. & 1 & 2 & 3 & 4 & 5 & \\
\hline 27 & The coaches talked to me about their expectations and goals for practice. & 1 & 2 & 3 & 4 & 5 & \\
\hline 28 & The coaches listened carefully to my explanations about why I disagreed with them. & 1 & 2 & 3 & 4 & 5 & \\
\hline 29 & I thought about how the coaches act before making an important decision. & 1 & 2 & 3 & 4 & 5 & \\
\hline 30 & As a team, we talked about how we can meet our personal and team goals. & 1 & 2 & 3 & 4 & 5 & \\
\hline 31 & Players on the team were given rewards for their good behavior. & 1 & 2 & 3 & 4 & 5 & \\
\hline 32 & The coaches asked for my opinion before setting up rules. & 1 & 2 & 3 & 4 & 5 & \\
\hline 33 & The coaches explained the reason for a team rule or punishment. & 1 & 2 & 3 & 4 & 5 & \\
\hline 34 & The coaches help me track my progress toward my goals. & 1 & 2 & 3 & 4 & 5 & \\
\hline 35 & The coaches tried a lot to help every player. & 1 & 2 & 3 & 4 & 5 & \\
\hline 36 & The coaches were fair to everyone. & 1 & 2 & 3 & 4 & 5 & \\
\hline
\end{tabular}

*Reversed Items

\section{Appendix: Turkish Form of Questionnaire}

\begin{tabular}{|c|c|c|c|c|c|c|}
\hline \multicolumn{2}{|r|}{$\begin{array}{l}\text { 1. Așağıda farklı kişilerin eylem ve düşüncelerini içeren ifadeler yer almaktadır. } \\
\text { Lütfen bu insanların ne kadar SízíN GíBİ olduğunu işaretleyerek belirtiniz. } \\
\text { Bu insanlar, }\end{array}$} & 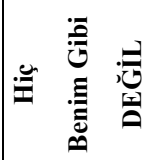 & 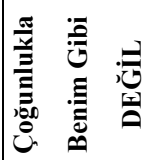 & 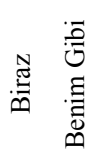 & 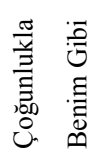 & 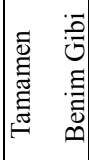 \\
\hline 1 & Takım arkadaşlarıyla aynı fikirde olmasalar da onlara saygı gösterirler. & 1 & 2 & 3 & 4 & 5 \\
\hline 2 & Hata yaptıktan sonra vazgeçmez denemeye devam ederler. & 1 & 2 & 3 & 4 & 5 \\
\hline 3 & Başka takımdaki oyunculara karşı asla kaba davranmazlar. & 1 & 2 & 3 & 4 & 5 \\
\hline 4 & Becerilerini geliştirmek için antrenman dışında da çalışmaya vakit ayırırlar. & 1 & 2 & 3 & 4 & 5 \\
\hline 5 & Kendi aralarında antrenörleri hakkında olumsuz yorumlar yaparlar.* & 1 & 2 & 3 & 4 & 5 \\
\hline 6 & İyi mücadele eden ya da galip gelen rakiplerini tebrik ederler. & 1 & 2 & 3 & 4 & 5 \\
\hline 7 & Yakalanmadıkları sürece kurallara uymalarına gerek olmadığına inanırlar.* & 1 & 2 & 3 & 4 & 5 \\
\hline 8 & Eğer oyunu kazanmalarına yardımcı olacaksa rakibine zarar verirler. * & 1 & 2 & 3 & 4 & 5 \\
\hline 9 & Takımları kaybediyor olsa bile mücadele etmeye devam ederler. & 1 & 2 & 3 & 4 & 5 \\
\hline 10 & Takımda kendi paylarına düşenleri yapmaları konusunda güvenilir. & 1 & 2 & 3 & 4 & 5 \\
\hline
\end{tabular}




\begin{tabular}{|c|c|c|c|c|c|c|}
\hline \multicolumn{2}{|r|}{$\begin{array}{l}\text { 2. Takım arkadaşlarınızı düşünün. Onlarla ilgili yazılı olan ifadelere KATILIP KATILMADIĞINIZI } \\
\text { belirtin. }\end{array}$} & \multirow[t]{2}{*}{ 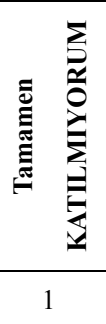 } & \multirow[t]{2}{*}{ ע2 } & \multirow[t]{2}{*}{ 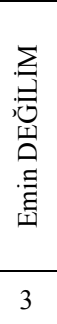 } & \multirow{2}{*}{ 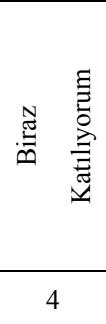 } & \multirow[t]{2}{*}{ 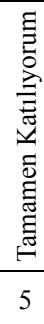 } \\
\hline 11 & Oyuncular birbirine güvenirler. & & & & & \\
\hline 12 & Oyuncular herhangi bir takım arkadaşlarını incittiklerinde bunu telafi etmeye çalışırlar (özür vb.). & 1 & 2 & 3 & 4 & 5 \\
\hline 13 & Oyuncular birbirleriyle ilgilenirler. & 1 & 2 & 3 & 4 & 5 \\
\hline 14 & Bu takımdaki oyuncular başkasına karşı kibardırlar. & 1 & 2 & 3 & 4 & 5 \\
\hline 15 & $\mathrm{Bu}$ takımdaki oyuncular kaybediyor olsalar da birbirlerini cesaretlendirirler. & 1 & 2 & 3 & 4 & 5 \\
\hline 16 & Bu takımdaki oyuncular birinin suçlandığını gördüklerinde bu durumu engellemeye çalışırlar. & 1 & 2 & 3 & 4 & 5 \\
\hline 17 & Oyuncular birbirlerinin yanı sıra çok iyi olmayan sporcuları da cesaretlendirirler. & 1 & 2 & 3 & 4 & 5 \\
\hline 18 & Bu takımda iyi olmayan sporcular suçlanır ya da dışlanırlar. * & 1 & 2 & 3 & 4 & 5 \\
\hline 19 & Oyuncular yeni becerileri geliştirmek için birlikte çalışırlar. & 1 & 2 & 3 & 4 & 5 \\
\hline 20 & Oyuncular takım arkadaşlarının kazanmak için hile yapmasını umursamazlar.* & 1 & 2 & 3 & 4 & 5 \\
\hline 21 & Oyuncular takım arkadaşlarının takım kurallarına uymaları için çaba gösterirler. & 1 & 2 & 3 & 4 & 5 \\
\hline 22 & Oyuncular mücadele eden takım arkadaşlarına yardım edebilmek için fazladan zaman ayırırlar. & 1 & 2 & 3 & 4 & 5 \\
\hline 23 & Oyuncular birbirleri hakkında dedikodu yaparlar.* & 1 & 2 & 3 & 4 & 5 \\
\hline
\end{tabular}

3. Antrenörleri ve takımı düşünün. Yazılı olanlar ne kadar SIKLIKLA oldu.

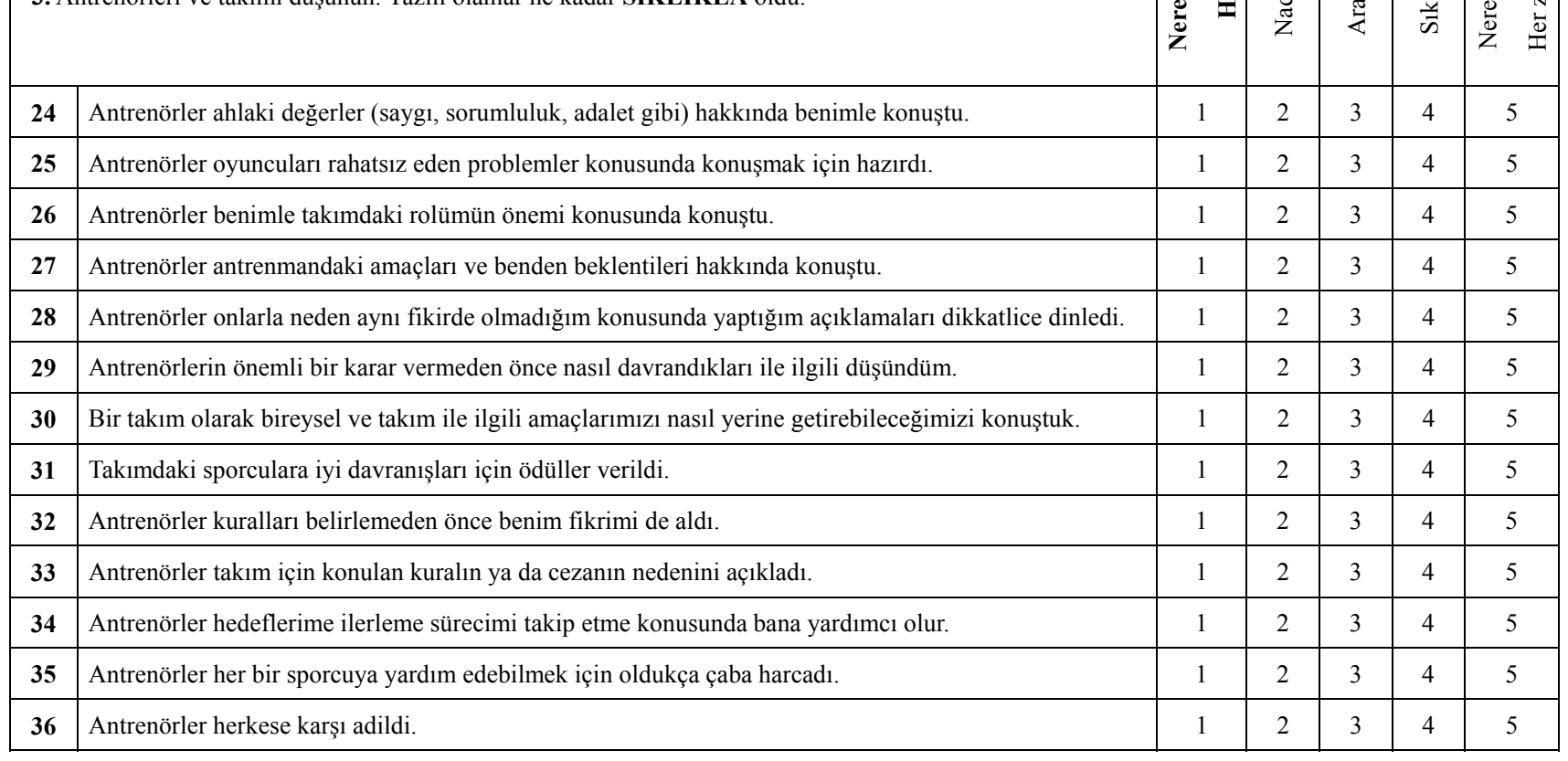

\section{*Olumsuz Maddeler}

\section{Copyrights}

Copyright for this article is retained by the author(s), with first publication rights granted to the journal.

This is an open-access article distributed under the terms and conditions of the Creative Commons Attribution license which permits unrestricted use, distribution, and reproduction in any medium, provided the original work is properly cited. 